\title{
Hubungan Kemandirian Belajar Dengan Hasil Belajar Siswa Sekolah Dasar Pada Mata Pelajaran Pendidikan Agama Islam di Masa Pandemic Covid 19
}

\author{
Ahmad Saefuddin', Ajat Rukajat ${ }^{2}$, Yayat Herdiana ${ }^{3}$ \\ Universitas Singaperbangsa Karawang \\ ahmadsaefuddin61@gmail.com ${ }^{1}$, ajat.rukajart@ staff.unsika.ac.id², \\ yayatherdiana19@gmail.com ${ }^{3}$
}

\begin{abstract}
Abstrak: Penelitian ini bertujuan untuk mengetahui hubungan kemandirian belajar dengan hasil belajar pada mata pelajaran Pendidikan Agama Islam di masa pandemic Covid 19. Penelitian menggunakan pendekatan kuantitatif dengan metode korelasional. Sampel penelitian sebanyak 32 siswa kelas V di SDN 2 Nagrikidul Purwakarta. Pengumpulan data menggunakan angket menggunakan aplikasi googleform dan dokumen hasil belajar siswa. Analisis data mengguakan bantuan SPSS versi 25 mencakup analisis deskriptif, uji asumsi (uji normalitas dan uji linearitas), uji korelasi, dan uji determinasi. Hasil penelitian menunjukkan bahwa kemandirian beljar siswa dalam kondisi kategori cukup $(3,33)$. Hasil belajar siswa pada pembelajaran PAI secara daring di masa pandemic berada pada kategori cukup $(78,13)$. Hasil uji signifikansi menunjukkan nilai signifikansi (2-tailed) $0,004<\alpha 0,05$, dengan nilai koefisien korelasi 0,532 dan koefisien determinasi 0,283. Ini menunjukkan terdapat hubungan positif kemandirian belajar dengan hasil belajar PAI sebesar 28,3\% sedangkan sisanya 71,7\% ditentukan variable lain.
\end{abstract}

Kata Kunci : Pendidikan Agama Islam; Kemandirin Belajar; Hasil Belajar, Pandemic

Abstract: This study aims to determine learning independence with learning outcomes in Islamic Religious Education subjects during the Covid 19 pandemic. The study uses a quantitative approach with the correlational method. The research sample was 32 fifth grade students at SDN 2 Nagrikidul Purwakarta. Collecting data using a questionnaire using the googleform application and student learning outcomes documents. Data analysis using SPSS version 25 includes descriptive analysis, assumption test (normality test and linearity test), correlation test, and determination test. The results showed that the students' learning independence was in sufficient condition (3,33). Student learning outcomes in PAI learning boldly during the pandemic are in the sufficient category $(78,13)$. The results of the significance test showed a significance value (2-tailed) of $0.004<0.05$, with a correlation coefficient of 0.532 and a coefficient of determination of 0.283 . This shows independent learning independence with PAI learning outcomes of $28.3 \%$ while the remaining $71.7 \%$ is determined by other variables.

Keywords: Islamic education; Independent Learning; Learning Outcomes, Pandemic. 


\section{Pendahuluan}

Sejak diberlakukannya pembelajaran dari rumah selama masa pandemic, melalui surat edaran Kementerian Pendidikan \& Kebudayaan Republik Indonesia melalui surat edaran Nomor 4 Tahun 2020 yang dikeluarkan pada 24 Maret 2020, perubahan signifikan dalam pelaksanaan pembelajaran PAI di sekolah dasar (Susanna, 2020). Pembelajaran yang awalnya mengedepankan pembelajaran luring atau tatap muka, beralih menjadi pembelajaran pembelajaran online dan juga pembelajaran Jarak Jauh (PJJ) (Anugrahana, 2020). Kementerian Pendidikan, Kebudayaan dan Riset Teknologi (Kemdikbudristek) menyatakan jumlah sekolah yang terdampak Covid-19 di Indonesia sebanyak 407.000 sekolah dengan 3,4 juta guru serta 56 juta siswa (Prasetyo, 2021). Data tersebut tidak jauh berbeda dengan data yang dikeluarkan oleh UNICEF yang melaporkan bahwa lebih dari 60 juta pelajar dan mahasiswa di Indonesia sementara tidak bersekolah karena COVID19 (Sikirit, 2020).

Lalu bagaimana hasil belajar siswa di masa pandemic? Hal ini tentu menjadi perbincangan di tengah situasi pro dan kontra kebijakan belajar dari rumah yang diterapkan di sekolah-sekolah. Berbagai kalangan pengamat, peneliti dan praktisi pendidikan mengakui bahwa telah terjadi penurunan kualitas belajar siswa selama diinlementasikannya pembelajaran jarak jauh (PJJ) selama pandemi Covid-19. Diakui pula oleh Jumeri selaku Direktur Jenderal Pendidikan Anak Usia Dini, Pendidikan Dasar dan Pendidikan Menengah Kemendikbud bahwa secara akademis tentu ada penurunan hasil belajar siswa karena bagaiamanapun guru-guru kita memberikan materi tentu total materinya jauh di bawah situasi normal ketika anak-anak itu belajar tatap muka (Ramadhan, 2021).

Studi pendahuluan pembelajaran PAI pada siswa kelas V di SDN 2 Nagrikidul Purwakarta, selama diberlakukannya intruksi belajar dari rumah pembelajaran dilaksanakan secara online dengan memanfaatkan beragam fasilitas online seperti Googleclassroom, whatsapp, youtube, dan zoom. Guru membagikan modul, bahan bacaan, dan sumber belajar lainnya melalui whatsapp dan googleclassroom termasuk mengontrol perkembangan belajar dan evaluasi. Namun, hasil belajar menunjukkan hasil yang belum optimal. Hasil belajar dari 32 siswa, sebanyak 43,75\% atau (14 orang siswa) memperoleh nilai tes ulangan harian berada di bawah KKM (kriteria ketuntasan minimal). Kuantitas siswa dalam hasil belajar PAI ini tentunya menambah daftar panjang problematika pembelajaran secara daring.

Secara umum, faktor-faktor yang mempengaruhi perkembangan belajar peserta didik dapat dibedakan menjadi tiga macam (Syachtiyani \& Trisnawati, 2021). Terdapat 3 faktor yang mempengaruhi hasil belajar siswa yaitu: (a) faktor internal (faktor dari dalam peserta didik), yakni keadaan/kondisi jasmani (aspek fisiologis) dan rohani peserta didik (aspek psikologis); (b) faktor eksternal (faktor dari luar peserta didik), yang meliputi lingkungan sosial dan lingkungan nonsosial; (c) faktor pendekatan belajar (approach to learning), yakni jenis upaya peserta didik yang meliputi strategi, dan metode yang digunakan peserta didik untuk melakukan kegiatan pembelajaran materi-materi pelajaran (Ellis \& Bliuc, 2019).

Fenomena yang terjadi pada pembelajaran PAI secara daring di masa pandemic sebagaimana hasil studi pendahuluan di kelas V SDN 2 Nagrikidul Purwakarta adalah sebagian besar siswa memiliki masalah dengan kemandirian belajarnya. Siswa tidak hadir dalam pembelajaran, abai terhadap tugas yang diberikan guru, mencontek tugas teman, tugas dikerjakan oleh orangtua, tidak membaca modul pembelajaran yang di share guru, 
tidak mengikuti pembelajaran sampai tuntas dan pasif dalam aktivitas pembelajaran. Sebagian siswa bahkan mengalami kesulitan mengontrol ketergantungan mereka terhadap game dan media social.

Kemandirian belajar siswa yang rendah, diasumsikan menjadi salah satu faktor yang mempengaruhi hasil belajar (Saefullah et al., 2013; Sari et al., 2021). Di tengah situasi pandemic di mana siswa dituntut belajar secara mandiri, maka jelas secara signifikan berdampak pada hasil belajar. Penelitian Widianti (2020) menunjukkan kemandirian belajar berpengaruh secara signifikan terhadap prestasi belajar siswa. Uki \& Ilham (2020) menjelaskan besarnya pengaruh adalah sebesar 72,59\%.

Pada siswa sekolah dasar, pembelajaran daring menuntut kemandirian belajar dari para siswa (Zahro \& Amalia, 2021). Bilda \& Fadillah (2020) dalam penelitiannya menemukan bahwa keberhasilan siswa dalam pembelajaran di masa pandemic ditentukan oleh kemandirian masing-masing individu untuk mencapai tujuan pembelejaran yang diharapkan. Afiqoh (2021) mengatakan bahwa kemandirian belajar berasal dari kata mandiri dan belajar. Kemandirian dapat diartikan sebagai kondisi yang memungkinkan seseorang untuk mengatur dan mengarahkan diri sesuai dengan tingkat perkembangannya (Tresnaningsih et al., 2019). Yamin (2012) menyatakan bahwa belajar mandiri adalah belajar yang bebas menentukan arah, rencana, sumber dan keputusan dalam mencapai tujuan akademik, tetapi tidak bebas dari keragaman aturan, kebiasaan atau masyarakat. Dengan demikian seorang siswa dikatakan mempunyai kemandirian belajar apabila mempunyai kemauan sendiri untuk belajar, siswa mampu memecahkan masalah dalam proses belajar, siswa mempunyai tanggung jawab dalam proses belajar, dan siswa mempunyai rasa percaya diri dalam setiap proses belajar.

Kemandirian belajar siswa dalam pembelajaran daring terlihat dari kemampuan siswa dalam mengatur waktu dan memanfaatkan berbagai sumber belajar. Artinya, untuk mencapai suatu pemahaman terhadap materi, siswa tidak bergantung pada materi yang diberikan guru. Kemandirian belajar merupakan usaha melakukan aktivitas belajar dengan cara mandiri atas dasar motivasinya sendiri untuk menguasai suatu materi tertentu sehingga bisa dipakai untuk memecahkan masalah yang sedang dihadapi, dengan demikian siswa yang mandiri harus proaktif serta tidak tergantung pada guru (Ambiyar et al., 2020). Lebih khusus mengenai sikap kemandirian belajar, pemerintah dalam peraturan menteri nomor 41 tahun 2007 menjelaskan bahwa sikap kemandirian belajar suatu sikap yang dimiliki individu untuk belajar dengan inisiatif sendiri dalam upaya menginternalisasi pengetahuan tanpa tergantung atau mendapat bimbingan langsung dari orang lain (Saefullah et al., 2013).

Beberapa penelitian lain pernah dilakukan mengenai kemandirian dan hasil belajar dengan focus mata pelajaran, jenjang satuan pendidikan, dan kondisi lingkungan yang berbeda. Pada penelitian kali ini, focus penelitian mengerucut kepada pembelajaran PAI di skeolah dasar di kelas $\mathrm{V}$ pada kondisi lingkungan belajar di tengah situasi pandemic Covid-19. Penelitian ini bertujuan untuk mendeskripsikan kemandirian belajar dan hasil belajar serta menganalisis korelasi antara kemandirian dengan hasil belajar siswa sekolah dasar dalam pembelajaran PAI secara daring di masa pandemic Covid-19. Diharapkan melalui penelitian ini dapat memberikan gambaran tentang kondisi objektif pembelajaran PAI di masa pandemic sehingga menjadi bahan evaluasi dan perbaikan kualitas Pendidikan Agama Islam di sekolah dasar. 


\section{Metode Penelitian}

Penelitian ini menggunakan pendekatan kuantitatif dengan metode korelatif (Creswell, 2014). Penelitian kuantitatif dimaksudkan untuk menjelaskan fenomena dengan menggunakan data-data numerik yang dalam analisisnya menggunakan statistik untuk meringkas sejumlah besar data (Sugiyono, 2016). Maka dalam penelitian kuantitatif sejak awal harus sudah jelas bagaimana mengkualifikasi (mengangkakan) datadata yang akan dikumpulkan, sehingga memungkinkan untuk dilakukan analisis dengan menggunakan statistic (Suharsaputra, 2012). Subjek penelitian adalah siswa kelas V SDN 2 nagrikidul Purwakarta sebanyak 32 siswa

Instrumen yang digunakan dalam penelitian ini adalah angket googleform untuk pengumpulan data kemandirian belajar. Angket menggunakan skala Likert (1-5) dan untuk data hasil belajar menggunakan data sekunder berupa nilai PAI siswa dari guru mata pelajaran PAI. Analisis data menggunakan software SPSS meliputi analisis deskriptif, uji asumsi (uji normalitas dan uij linearitas), uji korelasi, uji signifikansi, dan uji determinasi. Adapun untuk keperluan pengukuran dan analisis kuantitatif maka jawaban atas pertanyaan/pernyataan diberi skor yang dapat dilihat pada Tabel 1:

Tabel 1. Kriteria Skor Jawaban Angket

\begin{tabular}{llcc}
\hline No & \multicolumn{1}{c}{ Pilihan jawaban } & Skor & \\
& & $(+)$ & $(-)$ \\
\hline $\mathbf{1}$ & SLL (Selalu) & 5 & 1 \\
$\mathbf{2}$ & SR (Sering) & 4 & 2 \\
$\mathbf{3}$ & KD (Kadang-kadang) & 3 & 3 \\
$\mathbf{4}$ & HTP (Hampir Tidak Pernah) & 2 & 4 \\
$\mathbf{5}$ & TP (Tidak Pernah) & 1 & 5 \\
\hline
\end{tabular}

Data angket dianalisis kemudian dijadikan data kuantitatif dengan rentang skor (1 sampai 5). Setelah itu data yang telah diskor diinterprestasikan sesuai dengan tabel kriteria penilaian persentase skor seperti pada Tabel 2:

Tabel 2. Kriteria Penilaian Skor Penelitian

\begin{tabular}{ccc}
\hline No & Rentang Nilai/Skor & Kriteria \\
\hline 1. & $1,00-1,80$ & Tidak Baik \\
2. & $1,81-2,60$ & Kurang Baik \\
3. & $2,61-3,40$ & Cukup Baik \\
4. & $3,41-4,20$ & Baik \\
5. & $4,21-5,00$ & Sangat Baik \\
\hline
\end{tabular}

\section{Hasil dan Pembahasan}

\section{a. Kemandirian Belajar}

Pengumpulan data kemandirian dilaksanakan dengan melakukan survei angket secara online memanfaatkan googleform terhadap 32 siswa. Dalam penelitian ini pengukuran kemandirian belajar mengacu pada indicator yang dikemukakan oleh (Hidayat et al., 2020) dalam penelitiannya mencakup 1) ketidaktergantungan terhadap orang lain; 2) memiliki kepercayaan diri; 3) berperilaku disiplin; 4) memiliki rasa tanggung jawab; 5) berperilaku berdasarkan inisiatif sendiri; dan 6) melakukan kontrol diri. Hasil kemandirian belajar siswa kumulatif secara klasial ditunjukkan pada Gambar 1: 


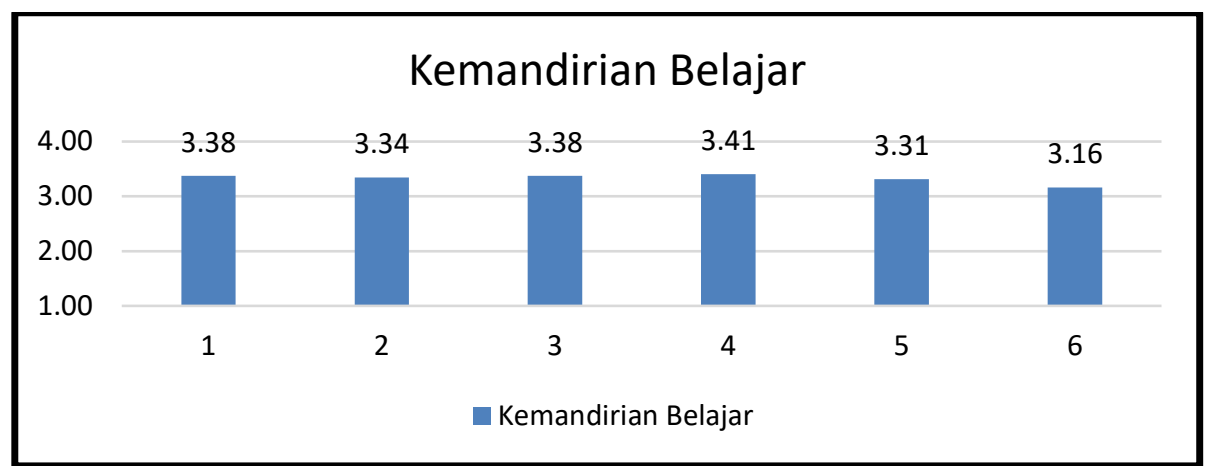

Gambar 1. Kemandirian Belajar Pada Pembelajaran PAI di Masa Pandemic

Keterangan:

1. Ketidaktergantungan terhadap orang lain

2. Memiliki kepercayaan diri

3. Berperilaku disiplin

4. Memiliki rasa tanggung jawab

5. Berperilaku berdasarkan inisiatif sendiri

6. Melakukan kontrol diri

Berdasarkan hasil pengolahan data survey, secara kumulatif rata-rata kemandirian belajar adalah 3,33 menunjukkan kemandirian beljar siswa dalam kondisi kategori cukup. Terdapat 7 orang siswa $(21,88 \%)$ memiliki kemandirian sangat tinggi, 4 orang siswa $(12,5 \%)$ dengan kemandirian tinggi, 14 orang siswa $(42,19 \%)$ dengan kemandirian cukup, dan 7 orang siswa $(23,44 \%)$ dengan kemandirian rendah.

Hasil analisis data secara deskriptif juga menunjukkan dari enam indicator kemandirian belajar yang diukur, hanya satu indicator dalam kategori baik atau tinggi yaitu pada aspek memiliki rasa tanggung jawab. Sementara lima indikator lain dalam kategori cukup. Artinya perlu dilakukan upaya meningkatan kemandirin belajar pada lima aspek agar siswa memiliki sikap ketidaktergantungan terhadap orang lain, memiliki kepercayaan diri, berperilaku disiplin, berperilaku berdasarkan inisiatif sendiri, dan mampu melakukan kontrol diri.

\section{b. Hasil Belajar PAI}

Pengumpulan data hasil belajar PAI dilaksanakan dengan metode dokumentasi yaitu peneliti mengumpulkan data sekunder berupa nilai hasil belajar siswa dari guru PAI kelas V SDN 2 Nagrikidul Purwakarta. Pada kurikulum 2013, penilaian hasil belajar siswa mencakup 3 aspek yaitu kognitif, psikomotorik, dan afektif. Adapun penelitian ini memfokuskan pada penilaian kognitif siswa. Hasil belajar siswa secara klasikal dilaporkan pada Gambar 2: 


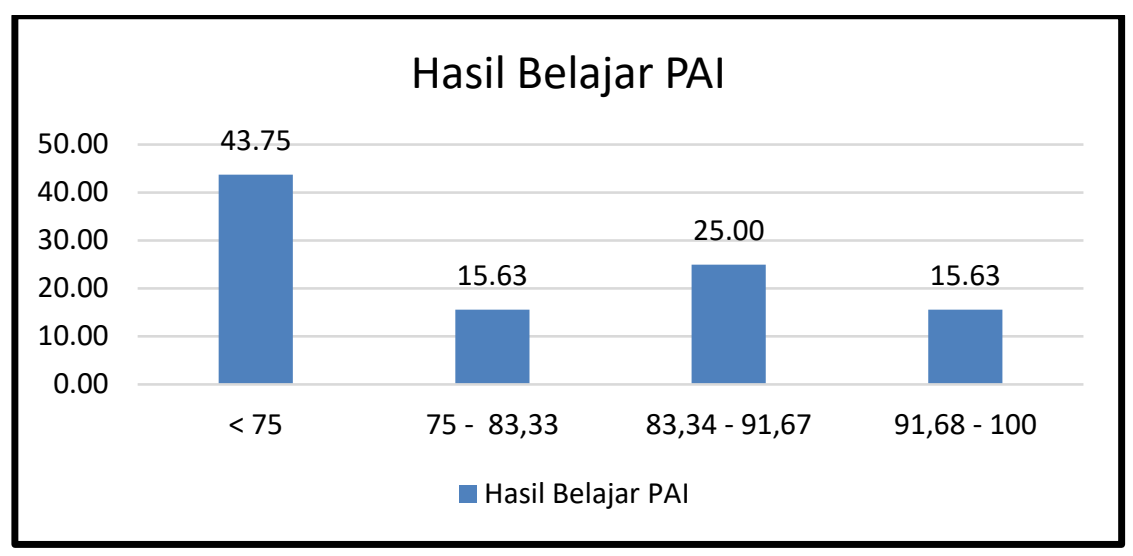

Gambar 2. Hasil Belajar PAI

Ketuntasan kriteria minimal (KKM) mata pelajaran PAI ditetapkan adalah pada angka 75. Dari 32 orang siswa, terdapat 14 orang siswa $(43,75 \%)$ memperoleh hasil belajar kurang (di bawah KKM), 5 orang siswa $(15,63 \%)$ memperoleh hasil belajar cukup baik, 8 orang siswa (25\%) dengan hasil belajar baik, dan 5 orang siswa $(15,63 \%)$ dengan hasil belajar sangat baik. Berdasarkan hasil pengolahan data hasil belajar, secara kumulatif rata-rata hasil belajar adalah 78,13. Ini menunjukkan secara klasikal hasil belajar siswa pada pembelajaran PAI secara daring di masa pandemic berada pada kategori cukup.

\section{c. Hubungan Kemandirian Belajar dengan Hasil Belajar}

Tahap selanjutnya adalah menganalisa hubungan kemandirian belajar dengan hasil belajar siswa pada pembelajaran PAI secara daring di masa pandemic Covid-19. Hipotesis yang diajukan sebagai berikut:

$\mathrm{H}_{0}$ : Tidak terdapat hubungan kemandirian belajar dengan hasil belajar PAI.

$\mathrm{H}_{\mathrm{a}}$ :Terdapat hubungan kemandirian belajar dengan hasil belajar PAI.

Sebelum melakukan uji hipotesis, dilakukan uji asumsi atau uji persyaratan analisis berupa uji normalitas dan uji linearitas data kemandirian belajar dan hasil belajar. Hasilnya dapat dilihat pada Tabel 3:

\section{Tabel 3. Uji Asumsi}

\begin{tabular}{cccccc}
\hline & & \multicolumn{2}{c}{ Uji Normalitas } & \multicolumn{2}{c}{ Uji Homogenitas } \\
No & Variabel & $\begin{array}{c}\text { Asymp. Sig. } \\
\text { (2-tailed) }\end{array}$ & Hasil & $\begin{array}{c}\text { Asymp. Sig. } \\
\text { (2-tailed) }\end{array}$ & Hasil \\
\hline 1 & Kemandirian Belajar & 0,718 & Normal & 0,613 & Linear \\
2 & Hasil Belajar & 0,432 & Normal & 0,613 & \\
\hline
\end{tabular}

Hasil uji normalitas menunjukkan data variable kemandirian dan hasil belajar berdistribusi normal. Demikian juga hasil uji linearitas kedua data variable pun menunjukkan hasil linear. Dengan demikian maka uji selanjutnya menggunakan uji parametrik. Berikutnya adalah melakukan analisis uji korelasi parametrik menggunakan korelasi product moment dari Pearson dengan signifikansi 0,05 (5\%). Hasil uji korelasi dideskripsikan pada Tabel 4: 
Tabel 4. Uji Korelasi

\begin{tabular}{|l|l|c|c|}
\hline \multicolumn{3}{|c|}{ Correlations } \\
\hline \multirow{4}{*}{ Kemandirian } & \multicolumn{2}{|c|}{ kemandirian } & Hasil Belajar \\
\cline { 2 - 4 } & Pearson Correlation & 1 & .004 \\
\cline { 2 - 4 } & Sig. (2-tailed) & & .532 \\
\cline { 2 - 4 } & $\mathrm{N}$ & 32 & 32 \\
\hline \multirow{3}{*}{ Hasil Belajar } & Pearson Correlation & .004 & 1 \\
\cline { 2 - 4 } & Sig. (2-tailed) & .532 & 32 \\
\cline { 2 - 4 } & $\mathrm{N}$ & 32 & \\
\hline
\end{tabular}

Hasil analisa korelasi dengan menggunakan Correlations Product Moment Pearson menunjukkan nilai signifikansi (2-tailed) $0,004<\alpha$ 0,05. Dengan demikian Ha diterima dan H0 ditolak, maka hubungan kemandirian belajar dengan hasil belajar PAI. Nilai koefesien korelasi sebesar 0,532 dengan korelasi positif. Artinya apabila kemandirian belajar siswa meningkat, maka hasil belajar siswa juga akan meningkat. Demikian pula sebaliknya, apabila kemandirian belajar siswa menurun, maka akan terjadi penurunan hasil belajar.

Tabel 5. Uji Determinasi

\begin{tabular}{|l|c|c|c|c|}
\hline \multicolumn{5}{|c|}{ Model Summary } \\
\hline Model & $\mathrm{R}$ & R Square & Adjusted R Square & $\begin{array}{c}\text { Std. Error of the } \\
\text { Estimate }\end{array}$ \\
\hline 1 & $.532^{\mathrm{a}}$ & .283 & .003 & 4.619 \\
\hline \multicolumn{2}{|l}{ a. Predictors: (Constant), kemandirian } \\
\hline
\end{tabular}

Hasil uji determinasi menunjukkan nilai $\mathrm{R}(0,532)$ dengan $\mathrm{R}^{2}(0,283)$. Koefisien determinasi sebesar 28,3 menunjukkan besarnya prosentase hubungan kemandirian belajar dengan preatsi belajar PAI adalah sebesar 28,3\%.

Hasil penelitian penulis menunjukkan adanya pengaruh signifikan sebesar 28,3\% kemandirian belajar terhadap hasil belajar. Hasil penelitian penulis sejalan dengan penelitian Bungsu et al. (2020) bahwa besar sumbangan kemandirian belajar terhadap hasil belajar sebesar 16\%. Penelitian Prayuda et al (2014) menyatakan sebesar 25,7\%, sedangkan Rahman et al (2021) menyatakan sebesar 48,1\%. Hasil lainnya adalah penelitian Ningsih \& Nurrahma (2016) bahwa individu yang memiliki kemandirian belajar yang tinggi dalam kegiatan belajar akan lebih cenderung memiliki intensitas proses belajar yang tinggi. Adapun tujuan yang akan dicapai individu tersebut adalah hasil dari belajar itu sendiri, baik dalam bentuk hasil belajar atau prestasi belajar.

Sementara hasil penelitian Aliyyah et al (2017) menunjukkan adanya pengaruh kemandirian belajar terhadap hasil belajar yaitu sebesar 53,50\% sedangkan 46,50\% dipengaruhi oleh variabel lain. Pengaruh dari variabel lain tersebut bisa meliputi minat belajar, motivasi belajar, kebiasaan belajar, dan lain-lain. Faktor yang mempengaruhi prestasi belajar tidak hanya kemandirian belajar saja, tetapi meliputi faktor minat belajar, motivasi belajar, kebiasaan belajar, dan faktor-faktor lain yang bersumber dari dalam diri siswa.

Hal yang tak kalah penting dalam upaya peningkatan prestasi belajar adalah kemandirian belajar. Kemandirian dalam belajar merupakan keharusan dan tuntutan 
dalam pendidikan saat ini. Secara umum, ada beberapa alasan yang berkaitan dengan pentingnya kemandirian belajar bagi siswa seperti, pentingnya kemandirian belajar bagi siswa dalam proses pembelajaran karena tuntutan kurikulum agar siswa dapat menghadapi persoalan di dalam kelas maupun di luar kelas yang semakin kompleks dan mengurangi ketergantungan siswa dengan orang lain dalam kehidupan sehari- hari (Fahradina et al., 2014).

Kemandirian belajar sangat penting bagi siswa dalam upaya meminimalisir fenomena-fenomena belajar yang kurang mandiri, seperti : tidak betah belajar lama di kelas atau belajar hanya menjelang ujian, membolos, menyontek, pasif di dalam kelas. Kemandirian belajar akan terwujud apabila siswa aktif mengontrol sendiri segala sesuatu yang dikerjakan, mengevaluasi dan selanjutnya merencanakan sesuatu yang lebih dalam pembelajaran yang dilalui dan siswa mau aktif di dalam proses pembelajaran yang ada. Dengan terwujudnya kemandirian belajar yang baik tentunya akan memberikan kontribusi yang cukup signifikan bagi peningkatan prestasi belajar siswa (Suhendri, 2011).

Ali dan Asrori (Widianti, 2020) menyebutkan sejumlah faktor yang mempengaruhi perkembangan kemandirian, yaitu :

1) Gen atau keturunan orangtua. Orang tua memiliki sifat kemandirian tinggi sering kali menurunkan anak yang memiliki kemandirian juga.

2) Pola asuh orang tua. Cara orang tua mengasuh dan mendidik anak akan mempengaruhi perkembangan kemandirian anak remajanya.

3) Sistem pendidikan di sekolah. Proses pendidikan di sekolah yang tidak mengembangkan demokrasi pendidikan dan cenderung menenkankan indoktrinasi tanpa argumentasi akan menghambat perkembangan kemandirian remaja sebagai peserta didik .

4) Sistem kehidupan di masyarakat. Sistem kehidupan masyarakat yang terlalu menekankan pentingnya hierarki struktur sosial, merasa kurang aman atau mencekam serta kurang menghargai manifestasi potensi remaja dalam kegiatan produktif dapat menghambat kelancaran perkembangan kemandirian remaja atau peserta didik .

Faktor-faktor yang mempengaruhi di atas kemandirian sangat menentukan sekali tercapainya kemandirian seseorang, begitu pula dengan kemandirian belajar peserta didik dipengaruhi oleh faktor dari dalam diri peserta didik itu sendiri, maupun yang berasal dari luar yaitu lingkungan keluarga, sekolah, lingkungan sosial ekonomi dan lingkungan masyarakat. Faktor-faktor tersebut mempunyai peranan yang sangat penting dalam kehidupan yang selanjutnya akan menentukan seberapa jauh seorang individu bersikap dan berfikir secara mandiri dalam kehidupan lebih lanjut. Dengan demikian, penulis berpendapat dalam mencapai kemandirian seseorang tidak lepas dari faktor-faktor tersebut diatas dan kemandirian peserta didik akan terwujud sangat bergantung pada peserta didik tersebut melihat, merasakan dan melakukan aktivitas belajar atau kegiatan belajar sehari-hari di dalam lingkungan tempat tinggalnya (Rahman et al., 2021).

\section{Kesimpulan dan Saran}

Selama diberlakukannya status darurat kesehatan pandemic Covid-19 pembelajaran PAI kelas V SDN 2 Nagrikidul Purwakarta dilaksanakan melalui pembelajaran jarak jauh atau secara daring/online. Hasil penelitian menunjukkan kemandirian belajar siswa dalam kondisi kategori cukup. Terdapat 7 orang siswa $(21,88 \%)$ memiliki kemandirian sangat tinggi, 4 orang siswa $(12,5 \%)$ dengan kemandirian 
tinggi, 14 orang siswa $(42,19 \%)$ dengan kemandirian cukup, dan 7 orang siswa $(23,44 \%)$ dengan kemandirian rendah. Hasil belajar siswa secara kumulatif berada pada rata-rata 78,13. berada pada kategori cukup. Hasil analisis korelasi menunjukkan terdapat hubungan positif kemandirian belajar dengan hasil belajar siswa pada mata pelajaran PAI sebesar 28,3\%. Kemandirian belajar menjadi kompetensi yang harus dimiliki siswa di tengah kondisi pembelejaran daring dan tuntutan kurikulum pendidikan agar siswa dapat menghadapi persoalan di dalam kelas maupun di luar kelas yang semakin kompleks dan mengurangi ketergantungan siswa dengan orang lain dalam kehidupan sehari- hari. Penelitian ini diharapkan dapat memberikan manfaat khususnya dalam mengevaluasi dan perbaikan pembelajaran PAI di masa pandemic. Diharapkan kepada penelitia selanjutnya melakukan penelitian dengan kajian, focus dan variable yang lebih luas sehingga hasil penelitian lebih komprehensif dan inovatif.

\section{Daftar Pustaka}

Afiqoh, N. W. (2021). Journal UMGESHIC Universitas Muhammadiyah Gresik Engineering, Social Science, and Health International Conference Vol 1 No 1 2021. 1(1), 114-129.

Aliyyah, R. R., Puteri, F. A., \& Kurniawati, D. A. (2017). the Influence of Independence Learning To Natural Sciences Learning Outcomes. 126-143.

Ambiyar, A., Aziz, I., \& Melisa, M. (2020). Perbedaan Kemandirian Belajar Siswa Pada Masa Pandemi di SMAN 1 Lembah Melintang dan SMAN 1 Lembah Gumanti. Jurnal Cendekia: Jurnal Pendidikan Matematika, 4(2), 1246-1258. https://doi.org/10.31004/cendekia.v4i2.367

Anugrahana, A. (2020). Hambatan, Solusi dan Harapan: Pembelajaran Daring Selama Masa Pandemi Covid-19 Oleh Guru Sekolah Dasar. Scholaria: Jurnal Pendidikan Dan Kebudayaan, 10(3), 282-289. https://doi.org/10.24246/j.js.2020.v10.i3.p282-289

Bilda, W., \& Fadillah, A. (2020). An Analysis of Students in Independent Learning of Analytic Geometry During the COVID-19 Pandemic. JTAM (Jurnal Teori Dan Aplikasi Matematika), 4(2), 166. https://doi.org/10.31764/jtam.v4i2.2575

Bungsu, T. K., Vilardi, M., Akbar, P., \& Bernard, M. (2020). Pengaruh Kemandirian Belajar Terhadap Hasil Belajar Matematika Di Smkn 1 Cihampelas. Journal On Education, 3(1), 91-95.

Creswell, J. W. (2014). Research Design Qualitative, Quantitative, and Mixed Method Approaches. SAGE Publication. Inc.

Ellis, R. A., \& Bliuc, A. M. (2019). Exploring new elements of the student approaches to learning framework: The role of online learning technologies in student learning. Active Learning in Higher Education, 20(1), 11-24. https://doi.org/10.1177/1469787417721384

Fahradina, N., Ansari, B. ., \& Saiman. (2014). Peningkatan Kemampuan Komunikasi Matematis dan Kemandirian Belajar Siswa SMP dengan Menggunakan Model Investigasi Kelompok Nova. Jurnal Didaktik Matematika, 01(01), 303-323.

Ningsih, R., \& Nurrahmah, A. (2016). Pengaruh Kemandirian Belajar dan Perhatian Orang Tua Terhadap Prestasi Belajar Matematika. Formatif: Jurnal Ilmiah Pendidikan MIPA, 6(1). https://doi.org/10.30998/formatif.v6i1.754 
Prasetyo, B. W. (2021). Kemdikbudristek: 407.000 Sekolah dan 56 Juta Siswa Terdampak Pandemi. Beritasatu.Com. https://www.beritasatu.com/nasional/769773/kemdikbudristek-407000-sekolah-dan-56juta-siswa-terdampak-pandemi

Prayuda, R., Thomas, Y., \& Basri, M. (2014). Pengaruh Kemandirian Belajar Terhadap Hasil Belajar Siswa Pada Mata Pelajaran Ekonomi Di Sma. Jurnal Pendidikan Dan Pembelajaran KhatulistiWA, 3(8).

Rahman, U., Idris, R., Majid, A. F., \& Sulasteri, S. (2021). The Influence of Interest and Independence of Learning on Student Math Learning Outcomes Pengaruh Minat dan Kemandirian Belajar Terhadap Hasil Belajar. 3(1), 24-37.

Ramadhan, A. (2021). Kemendikbud Akui Pembelajaran Jarak Jauh Menurunkan Kualitas Belajar.

Kompas.Com. https://nasional.kompas.com/read/2021/01/23/14201841/kemendikbud-akuipembelajaran-jarak-jauh-menurunkan-kualitas-belajar

Saefullah, A., Siahaan, P., \& Sari, I. . (2013). Hubungan Antara Sikap Kemandirian Belajar Dan Prestasi Belajar Siswa Kelas X Pada Pembelajaran Fisika Berbasis Portofolio. WaPFi (Wahana Pendidikan Fisika), 1(1), 26-36. https://doi.org/10.17509/wapfi.v1i1.4891

Sari, P. P., Hidayah, N., Najibufahmi, M., \& Pekalongan, U. (2021). Pengaruh Kemandirian dan Kreativitas Belajar terhadap Prestasi Belajar Matematika dalam Pembelajaran Daring. Jurnal Pendidikan Matematika, 01(01), 71-82.

Sikirit, D. (2020). Learning from home during the COVID-19 pandemic With her school closed, 6-year-old Moreyna strives to continue learning at home in Papua. UNICEF Indonesia. https://www.unicef.org/indonesia/coronavirus/stories/learning-home-duringcovid-19-pandemic

Sugiyono. (2016). Metode Penelitian Kombinasi (Mix Methode). Alfabeta.

Suharsaputra, U. (2012). Metode Penelitian Kuantitaif Kualitatif dan Tindakan. Refika Adhitama.

Suhendri, H. (2011). Pengaruh Kecerdasan Matematis-Logis dan Kemandirian Belajar terhadap Hasil Belajar Matematika. Formatif: Jurnal Ilmiah Pendidikan MIPA, 1(1), 2939. https://doi.org/10.30998/formatif.v1i1.61

Susanna, D. (2020). When will the COVID-19 pandemic in indonesia end? Kesmas, 15(4), 160-162. https://doi.org/10.21109/KESMAS.V15I4.4361

Syachtiyani, W. R., \& Trisnawati, N. (2021). Analisis Motivasi Belajar Dan Hasil Belajar Siswa Di Masa Pandemi Covid-19. Prima Magistra: Jurnal Ilmiah Kependidikan, 2(1), 90-101. https://doi.org/10.37478/jpm.v2i1.878

Tresnaningsih, F., Santi, D. P. D., \& Suminarsih, E. (2019). Kemandirian Belajar Siswa Kelas Iii Sdn Karang Jalak I Dalam Pembelajaran Tematik. Pedagogi: Jurnal Penelitian Pendidikan, 6(2), 51-59. https://doi.org/10.25134/pedagogi.v6i2.2407

Uki, F., \& Ilham, A. (2020). Pengaruh Kemandirian Belajar Siswa Terhadap Prestasi Belajar 
di SDN 03 Limboto Barat Kabupaten Gorontalo. Aksara: Jurnal Ilmu Pendidikan Nonformal, 6(1), 89. https://doi.org/10.37905/aksara.6.1.89-95.2020

Widianti, M. (2020). Pengaruh Kemandirian Belajar Terhadap Prestasi Belajar Bahasa Indonesia Pada Siswa Kelas Xi Sma Di Kota Depok Jawa Barat. LITERASI: Jurnal Ilmiah Pendidikan Bahasa, Sastra Indonesia Dan Daerah, 10(Volume 10), 42-53. https://doi.org/10.23969/literasi.v10i1.2052

Yamin. (2012). Desain Baru Pembelajaran Konstruktivistik. Referensi.

Zahro, I. F., \& Amalia, R. (2021). Deskripsi Kemandirian Siswa dalam Pembelajaran Daring Pada Masa Pandemi Covid. Attanwir: Jurnal Keislaman Dan ..., 12(1). http://ejurnal.staiattanwir.ac.id/index.php/attanwir/article/view/50 